whispered but easily audible comments about their bodies, their " glands " and their genitals.'

The section on the care of children in the tropics by A. W. Woodruff, although clearly written, will not be full enough as a reference book for practitioners in some countries. In particular, greater emphasis might have been laid on the practical difficulties of the preventive measures advocated.

\section{ALLERGY IN CHILDHOOD}

By Jerome Glaser, M.D. Pp. xxii + 529, with 42 illustrations, many in colour. Oxford: Blackwell Scientific Publications. 1956. 90s.

Your reviewer picked up this book expecting to find much of its contents unacceptable to a British paediatrician, who believes that family doctors and paediatricians rather than allergists should give advice about most allergic disorders in childhood. He was pleased to find that Dr. Glaser has a very practical outlook and does not wish to make his patients too dependent on the physician.

It is most curious that in the United States breathing exercises are not usually considered an important part of the management of children with asthma. The more pleasing is it to find the Asthma Research Council's publication described as ' a very splendid little booklet ' and to learn that Dr. Glaser considers physiotherapy ' a fertile. and productive field for investigation.'

For the reader who wishes to refer to original sources there are useful lists of references (covering European as well as American writings) to each chapter; these will be particularly useful where the chapters are short and do not attempt to cover all aspects of the condition discussed-e.g. anaphylactoid purpura, polyarteritis, erythema nodosum.

The book is primarily intended for American readers - to them the detailed footnotes about proprietary preparations will be very valuable.

T.S.

\section{A TEXTBOOK OF CLINICAL PATHOLOGY}

Edited by Skward E. Miller, M.D. Fifth edition. Pp. xxix $+1,208$. London: Ballière, Tindall and Cox. r $956.88 \mathrm{~s}$.

'Clinical Pathology' is a branch of medicine peculiar to Anglo-Saxon countries. It now covers such a wide field of laboratory investigation that it is not surprising to find ten contributors taking part in this textbook. The first six chapters ( 370 pages) are taken up by a conventional account of cytological and serological haematology. For the cells, the 'new' terms are used, but their synonyms are given. The chapters on blood chemistry and on hepatic tests offer sound theory, but it would be difficult for anyone to carry out the tests discussed merely with the help of the outlines given. Assay of antibiotics, diagnosis of virus diseases, and immunological tests are discussed in the next few chapters and these are followed by accounts of medical bacteriology and mycology. Although the chapter of medical parasitology is a particularly useful one, Fig. 14.13 should be eliminated; it only repeats Fig. I2.I5A. Assay of vitamins and of hormones are briefly sketched. Chapters on exfoliative cytology, diagnosis of venereal lesions, cerebrospinal fluid, renal function and urine tests, sputums, gastric contents, seminal fluid and faeces follow.

This textbook certainly does what it sets out to do, to convey 'how to use the clinical laboratory most advantageously,' a matter often neglected by the clinician.

E.N.

\section{THE ROYAL NORTHERN HOSPITAL, $1856-1956$}

By Eric C. O. Jewesbury, M.A., D.M., M.R.C.P. Pp. xii + 157, with 23 illustrations. London : H. K. Lewis \& Co. Ltd. I 956. I7s. 6d.

The story of the Royal Northern Hospital, now celebrating its rooth year, makes both interesting and entertaining reading, and once begun this book is hard to put down. Many of the illustrations are also of great historical interest. Founded by a 30-year old surgeon who was dismissed from a staff appointment at University College Hospital for 'vulgar behaviour', one is now perhaps amused by some of the hospital's earlier struggles and innumerable difficulties. The Royal Northern Hospital, however, was 'born with good lungs' and soon rose to fame owing to the strength of will of the earlier members of the staff who often drained their pockets to provide this necessary service to a quarter of a million of the population. It is also good to note the galaxy of famous men who have been pleased to serve this Hospital which still retains the true 'voluntary' spirit.

Highly recommended to all interested in the ways by which the sick have been provided for in this country, visitors from overseas especially will find this short book illuminating with regard to British medicine over an exciting century. 